\title{
A Tentative Study of Error Correction Strategies in English Class for Non-English Majors
}

\author{
Haixia Yin* \\ Xi'an Fanyi University, Chang'an District, Xi'an City, Shaanxi Province, China \\ fiona_xn@126.com
}

Keywords: Error correction; College english class; Non-english majors

\begin{abstract}
Since the 1950s, error correction has aroused much attention in the studies of second language learning. Lots of linguists have studied deeply in the field of error correction. In the past few decades, more and more linguists came to realize the functions and necessity of error correction in the process of learning a foreign language, and a large number of studies related to classroom error correction have been carried out. The author aims to find out the current condition of error correction in the English classroom for non-English majors as well as the differences between teachers' and students' attitudes towards error correction in class, and finally to provide some suggestions about the strategies of error correction for English teachers.
\end{abstract}

\section{Attitudes towards Error Correction}

With the rapid development of globalization, English has become an international language for exchanging information in various fields, and it has been learned by more and more people all over the world. Since the implementation of the policy of the reform and opening-up in 1979, English learning has become increasingly popular in China. As is known to all, the primary purpose of English learning is communication. Yet the oral communication ability of most Chinese English learners is relatively poor, especially the students. They usually attach too much importance to written English for passing exams. Therefore, lots of students who have learned English for many years still cannot communicate with foreigners very well.

For students, in the course of second language learning and acquisition, making errors is very common and inevitable. So, should the oral errors be corrected? What is the proper way to correct them? What are the students' and teachers' attitudes towards error correction? Can students benefit from in-class oral correction? Such questions have aroused lots of attention in recent years.

Teachers' Belief about Error Correction. As to teachers' belief of error correction, it's difficult to summarize in that teachers hold various attitudes towards the necessity of error correction, the impact of error correction on students' self-confidence and the effectiveness of error correction in improving students' oral English. However, despite the differences, the teachers' attitudes are moderately balanced. The teachers who support error correction do not like the way in the 1950s and 1960s when "all errors in oral production were considered to be negative and should always be corrected without questions" while the teachers who do not think highly of error correction disagree with it and they suggest an indirect way of error correction. As a matter of fact, not all the teachers believe that error correction is helpful to improve students' oral English.

The teachers do have something in common as to the matter of error correction.

First, they won't try to correct all the errors made by students. Littlewood points out learners shouldn't be constantly corrected, and errors should be regarded with greater tolerance, as a completely normal phenomenon in the development of communicative skills. According to the results of the class observation, it seems that the teachers may share the same idea as Littlewood, because they have shown much tolerance towards students' errors and they choose to correct errors selectively.

Second, teachers prefer to correct errors when the students' conversations or speeches are finished. That is to say, they prefer postponed correction.

Third, Lyster and Ranta find that all teachers they observed in the content-based French 
immersion classes used recasts more than any other type of feedback. The different feedback types are presented below in the order of the highest to lowest frequency. They are recasts, elicitation, clarification requests, metalinguistic feedback, explicit correction and repetition. In this study, the result is quite similar to Lyster and Ranta's findings: elicitation is generally favored by all the teachers as the first choice when correcting errors, followed by recast and repetition. However, according to the findings of classroom observation, the use of recast is more often than that of elicitation, due to the time-saving feature of recast. So, there is a distinction between teachers' concept and their practice in class on this issue. And also there is a mismatch between the teachers' and the students' favorite methods of error correction for the students enjoy elicitation most.

Students' Attitude towards Error Correction. Cathcart and Olsen find that ESL learners like to be corrected by their teachers and want more correction than they are usually provided with. They generally support error correction in English class, regarding error correction as quite necessary and helpful. It is understandable that the learners are willing to be corrected by the teachers and actually dependent on correction from English teachers. And, if they talk with native speakers, they are also willing to be corrected.

The learners' preference for error correction is much diversified, despite the fact that there are some agreements reached by a majority of the students. As to the question of whether their mistakes should be corrected wholly or corrected selectively, students have different opinions. Most of them agree with selective correction while a lot of students think all errors should be corrected. As to the timing of correction, most of students don't like to be interrupted to correct errors. Recast, elicitation, and repetition are the most three preferred ways of correction. While correcting errors, teachers should pay attention to the individual learners' differences, as James put forward: The relative effectiveness of correction techniques will depend on individual differences such as the learners' level of attainment in English learning. This means correction must consider about the proficiency and individual differences. So students' preferences for certain types of correction cannot be ignored and a match between correction and students' preferences is highly recommended.

Students should take responsibility for their own learning, and they should be the central figure of learner-autonomy in language learning. Learning language for communication involves in developing increasing capacities to make choice (of language and meaning), to get along with others and to develop one's own voice in another language. It is a major part of language teacher's role to create conditions which support this development and improve students' ability. Through the learners' strong preference for elicitation, it is perceivable that students have the awareness and partial ability to do self-correction, but such awareness and ability should be enhanced. Thus, in English classroom, teachers should encourage students to do self-correction by applying more elicitation.

\section{Strategies of Error Correction}

Here are five research questions about error correction which were raised based on Chaudron's model. They are respectively: Whether students' oral errors in English class should be corrected; What oral errors in English class ought to be corrected; When to correct students' oral errors in English class; How to correct students' oral errors in English class; Who should correct students' oral errors in English class.

Whether Students' Errors in English Class Should Be Corrected. Most teachers and students hold the positive attitudes towards error feedback and think that error correction can effectively improve learners' accuracy of spoken English. However, differences still exist: With regard to errors in the oral performance, students have stronger will that these errors should be corrected, which may result from the high demand for accuracy in the traditional teaching method; The majority of teachers object to correcting all the errors, while most of the students consider all the errors should be corrected whenever they occur in class; Teachers prefer to correct the errors selectively and think only those errors that impact the communication should be corrected, but many students hope most of their errors can be corrected by the teacher; Many teachers don't think that it's appropriate to 
give too much corrective feedback because it may frustrate the students and decrease their confidence, while more than half of the students think over-correction will have no negative effects on their learning confidence.

What Errors in English Class Ought to Be Corrected. Both teachers and students think that the four categories of errors (phonological errors, lexical errors, grammatical errors, pragmatic errors) should be corrected. For the students, due to the great pressure of passing CET-4, lexical and grammatical errors are considered as the ones that mostly need to be corrected (Grammatical > Lexical > Phonological > Pragmatic); while for the teachers, which should be corrected in the first place are pragmatic errors and phonological errors (Pragmatic > Phonological > Lexical > Grammatical) because both of the pragmatic rules and the phonological principles affect the smooth going of communication to a great extent.

Although there is a significant differences between teachers' and students' attitudes towards the correction frequency of lexical errors and grammatical errors, the teachers' and the students' attitudes towards the correction frequency about phonological and pragmatic errors are almost $t$ he same.

When to Correct Students' Errors in English Class. Most teachers would like to correct the errors after students' presentation because they are afraid to interrupt the students' thought flow, which may bring them the anxiety and finally influence their confidence in English learning. Yet many students would like their errors to be corrected immediately in the mid-sentence because they often commit more than one error during the presentation, so they are afraid that if errors are corrected after their presentation, it will not help them recall their memory about the errors they made; therefore it will leave no deep impression in their minds; however, the immediate treatment can help them remember the errors they have committed better.

How to Correct Students' Errors in English Class. No teacher would like to correct students' phonological errors by using the elicitation because they think students cannot get any help from this feedback method. More than half of the students think their teachers should use explicit correction on lexical and grammatical errors, while near half of the teachers will correct these errors by offering meta-linguistic clues because this kind of feedback can elicit the students and help them do self-repair. Students' needs for teachers' explicit correction result from their needs for the great achievement in the next performance, and they want to get the clear and direct correction from the teacher in order to recognize and learn the error immediately and avoid making the same error next time. The explicit correction given by teachers cannot satisfy the needs of the students for this kind of feedback.

Who Should Correct Students' Errors in English Class. There exists no great difference in students' and teachers' attitudes towards who should correct the learner oral errors. The majority of students consider the teacher to be the one who should correct the learners' errors because they think teacher is the high authority in class and what the they say will definitely be right. In fact, most teachers think that grammatical errors should be corrected by the students themselves. Teachers' attitude that except the teacher, students themselves should also try to correct their errors is in accordance with the role of students in today's classroom, and through self-correction, students will remember and learn from the errors better.

\section{Conclusion}

Error correction is a complex process since it has a close relation to students' affection problems. Through the research and the observation, the author has reached the conclusion that what teachers have done in class does not satisfy their students' needs, and that students have strong desire of hoping teachers to correct their errors in class. Therefore, teachers should realize their students' expectations and try to find a solution to meet the students' need. Meanwhile, teachers ought to improve their own professional abilities to be more qualified, and the education authority and institute should also improve the facilities for College English teaching and research so that College English teachers can get more opportunities to improve themselves. 


\section{References}

[1] T. Hedge, Teaching and Learning in the Language Classroom, Oxford: Oxford University Press, 2002.

[2] S. Krashen, T. D. Terrell, The Natural Approach to Language Acquisition in the Classroom, Oxford: Pergamon Press, 1983.

[3] W. Littlewood, Foreign and Second Language Learning, Beijing: Foreign Language Teaching and Research Press, 2000.

[4] J. Z. Chen, Error Analysis and Correction Strategies in Oral English, Journal of Harbin University, Vol. 25 (2004), P104-107. (In Chinese)

[5] C. James, Errors in Language Learning and Use: Exploring Error Analysis, Beijing: Foreign Language Teaching and Research Press, 2001.

[6] C. Chaudron, Second Language Classroom: Research on Teaching and Learning, U. K.: Cambridge University Press, 1988.

[7] D. M. Ma, The Students' Self-correction after Speaking Activities in the English Teaching Group, Foreign Language Teaching and Research, Vol. 02 (2002), P21-25. (In Chinese)

[8] X. Q. Yan, Error Analysis and Foreign Language Teaching, Journal of Jiangxi Education College (Social Sciences), Vol. 20 (1999), P38-40. (In Chinese) 